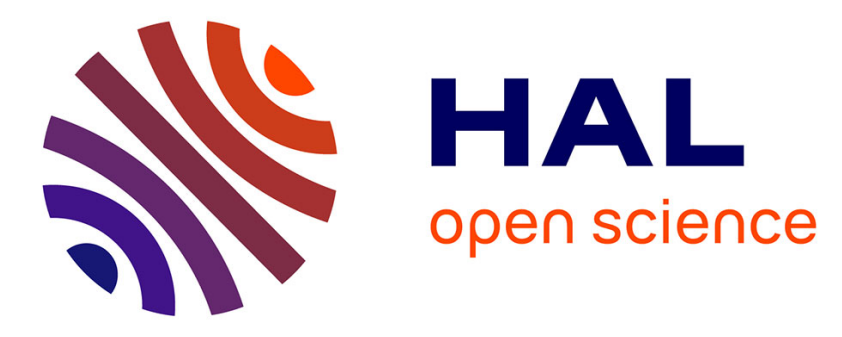

\title{
Introduction: Complex Adpositions and Complex Nominal Relators
}

Benjamin Fagard, José Pinto de Lima, Elena Smirnova, Dejan Stosic

\section{To cite this version:}

Benjamin Fagard, José Pinto de Lima, Elena Smirnova, Dejan Stosic. Introduction: Complex Adpositions and Complex Nominal Relators. Benjamin Fagard, José Pinto de Lima, Dejan Stosic, Elena Smirnova. Complex Adpositions in European Languages: A Micro-Typological Approach to Complex Nominal Relators, 65, De Gruyter Mouton, pp.1-30, 2020, Empirical Approaches to Language Typology, 978-3-11-068664-7. 10.1515/9783110686647-001 . halshs-03087872

\section{HAL Id: halshs-03087872 \\ https://shs.hal.science/halshs-03087872}

Submitted on 24 Dec 2020

HAL is a multi-disciplinary open access archive for the deposit and dissemination of scientific research documents, whether they are published or not. The documents may come from teaching and research institutions in France or abroad, or from public or private research centers.
L'archive ouverte pluridisciplinaire HAL, est destinée au dépôt et à la diffusion de documents scientifiques de niveau recherche, publiés ou non, émanant des établissements d'enseignement et de recherche français ou étrangers, des laboratoires publics ou privés. 
Benjamin Fagard, José Pinto de Lima, Elena Smirnova \& Dejan Stosic

\section{Introduction: Complex Adpositions and Complex Nominal Relators}

Benjamin Fagard

CNRS, ENS \& Paris Sorbonne Nouvelle; PSL

Lattice laboratory, Ecole Normale Supérieure, 1 rue Maurice Arnoux, 92120 Montrouge, France

benjamin.fagard@ens.psl.eu

José Pinto de Lima

Universidade de Lisboa, Faculdade de Letras

Rua Professor Simões Raposo, ${ }^{\circ}$ 20, 3-B, 1600-662 LISBOA, Portugal

pintodelima@outlook.pt

Elena Smirnova

Institut de langue et littérature allemandes

Université de Neuchâtel

Espace Tilo-Frey 1

CH-2000 Neuchâtel

elena.smirnova@unine.ch

Dejan Stosic

University of Toulouse Jean Jaurès \& Laboratory CLLE (CNRS \& UT2J)

5, allées Antonio Machado, 31058 Toulouse Cedex 9, France

dejan.stosic@univ-tlse2.fr 
In this introductory chapter, we address the issue of the existence and definition of complex adpositions - and complex nominal relators in general -, and provide a working definition on the basis of the existing literature on the subject. The existence of simple adpositions as a word class is now consensual, despite a long and convoluted history, which has seen them equated among other things with conjunctions, adverbs and prefixes (Auroux 1989-2000), for obvious reasons of functional proximity. They are generally considered to be monomorphemic relational expressions whose main function in language is to introduce noun or noun phrases. Research on simple adpositions has been quite wide-ranging, from a theoretical perspective (e.g. Lindqvist 1994, Kurzon \& Adler 2008, Libert 2013), and their typological variation has been given some attention already (Svorou 1994, Hagège 2010, Fagard 2010), with a wealth of studies on adpositions in individual languages such that we could not list them all (see e.g. Vaguer 2006 for a non-exhaustive list of 1,535 references on simple adpositions).

The status of complex adpositions (henceforth CAs), conversely, is not entirely consensual. For instance, Seppänen et al. conclude their analysis of CAs in English as follows:

Introduced into the grammar on the basis of an untenable analysis, the class of complex prepositions as defined by Quirk et al. is empty, and the term itself is thus not helpful in the description of English. (Seppänen et al. 1994: 25)

At any rate, CAs have received much less attention than simple adpositions. There are very few book-length studies on the subject: to our knowledge, the only counter-examples are studies on their development in Spanish (Cifuentes Honrubia 2003), English (Hoffmann 2005), Russian (Šiganova 2001) and Estonian (Jürine 2016). Aside from that - and from mentions of complex adpositions in grammars (e.g., for English, Quirk et al., 1985) and in studies of adpositions in general (e.g. Di Meola 2000, Fagard 2010) -, most studies on complex adpositions are article length studies, often bearing on a subset of complex adpositions, in a given European language: English (Schwenter \& Traugott 1995), Dutch (Hüning 2014, Bree 2014), French (Borillo 1991, 1997, Adler 2007, 2008), Portuguese (Lima 2014, 2019a, 2019b), Romanian (Ciobanu 1957, Găitănaru 1965, 1999, Căpăţână 2000, 2003). Few papers are devoted to the study of complex adpositions in a more general (e.g. in Romance languages, Fagard \& Mardale 2007) or theoretical perspective (Seppänen et al. 1994, Meibauer 1995, Adler 2001), as well as a few papers comparing simple and complex adpositions (e.g. Fagard \& De Mulder 2007, Fagard 2012). Finally, there is a growing body of descriptive papers which provide accounts of the paradigms of complex adpositions in individual languages, e.g. in French (Borillo 1997, Stosic \& Fagard 2019), Italian (Piunno \& Ganfi 2017), Occitan (Sibille 2019), Romanian (Fagard \& Mardale 2019).

It now seems possible to build on this growing body of (mostly descriptive) works on complex adpositions, and provide a global account of CAs in European languages. This is what this volume aims for. In order to move on from these descriptions to a wider typological overview, however, some common grounds seem necessary. In this chapter, we propose first an overview of the main features of simple (Section 1) and complex (Section 2) adpositions, before providing working definitions for both, including a discussion of adpositions vs relators (Section 3). We then focus on the main research questions addressed in the chapters of the book (Section 4), before presenting briefly each chapter (Section 5). 


\section{Simple adpositions: Basic features and description}

The many studies on simple adpositions, especially those in the $20^{\text {th }}$ and early $21^{\text {st }}$ century, have made it possible to provide a consensual definition of the class. Before defining them, however, let us first take a look at what, in European languages, is generally called 'adposition'.

\subsection{Pre-, post-, ambi- and circumpositions}

Adpositions are a category under which prepositions (1) and postpositions (2) are subsumed, as well as less frequent formations, such as circumpositions (3). Sometimes, an adposition may occur pre- and postnominally; in such cases, one speaks of ambipositions (4).

(Italian)

(1)

$\begin{array}{llllll}\text { Questi } & \text { parea } & \text { che } & \text { contra } & \text { me } & \text { venisse } \\ \text { DEM.M.SG } & \text { seem.PST.3SG } & \text { PRO.REL } & \text { towards } & \text { PRO.1SG.ACC } & \text { come.PST.SBJ.3sG }\end{array}$

'He seemed to be coming towards me' (Dante, Inferno, I, 46)

(Dutch)

$\begin{array}{lllll}\text { (2) } & \text { I } k & \text { ben } & \text { er } & \text { tegen } \\ & \text { PRO.1SG.NOM } & \text { be.1SG } & \text { PRO.DEI } & \text { against } \\ & \text { 'I'm against it' (Multatuli, Max Havelaar, 4) } & \end{array}$

(German)

(3) um Lebens oder

for life.GEN.SG or

bitt' ich mir

Sterbens willen,

death.GEN.SG sake

ask.1SG PRO.1SG.NOM PRO.1SG.DAT DET.IND.NOM.SG pair

'For the sake of life or death, I ask for myself a few lines' (Goethe, Faust)

(4)

$\begin{array}{llllll}\begin{array}{l}\text { wegen } \\ \text { because }\end{array} \text { DET.M.GEN.SG } & \text { Unwetters } & \text { storm.GEN.SG } \\ \text { 'because of the storm' } & & \text { DET.M.GEN.SG } & \text { Snwetters } & \text { segen } \\ \text { serm.GEN.SG } & \text { because }\end{array}$

\subsection{Syntactic features (/Distributional)}

Syntactically, adpositions are basically relational expressions: an adposition establishes a grammatical relationship linking two other elements, one of which is a governing word while the other is a governed expression, commonly called "complement". This results in a tripartite schema that could be tentatively noted [A R B] (where "R" stands for relator, meaning the adposition; cf. Pottier 1962, Cervoni 1991, Cadiot 1997, Hagège 1997, De Mulder \& Stosic 2009). As is well known, this relation is an asymmetrical one, since the adposition has a stronger relationship with its complement than with its governor, so that [A [R B]] would actually be a better way of describing it. Saying that the adposition is the head of phrase, called "adpositional phrase”, captures this asymmetrical relation. Thus, one can distinguish "prepositional”, "postpositional" and "circumpositional” phrases depending on where the adposition is used with regard to its complement (B). 
Most often, adpositions take as complements non-propositional expressions, the prototype of which are noun phrases (including pronouns, see 1-4 above), but many other kinds of syntactic structures can be introduced by adpositions, such as adjectival, adverbial, or prepositional phrases (see 5-7):

(French)

(5)

\begin{tabular}{|c|c|c|c|}
\hline De & modest & $\begin{array}{l}\text { il } \\
\text { he }\end{array}$ & $\begin{array}{l}\text { est } \\
\text { AUX.PRS.3SG }\end{array}$ \\
\hline
\end{tabular}

'From modest, he has become very haughty'

(French)

(6) Fais-

moi $\quad$ ça

pour

[demain]

do.IMP.PRS.2SG me.DAT

this

for

tomorrow

'Do this for me tomorrow'

(French)

(7) $\mathrm{Tu}$ pars de [devant la ligne jaune]

You start.PRs.2sG from in.front.of the line yellow

'You start from in front of the yellow line'

Adpositions are also found to introduce other types of complements, namely subordinate clauses. However, one should distinguish between cases where the function of adpositions is the same as in other uses (8-9) and those where their status is more problematic, as in examples (10-11):

(Serbian)

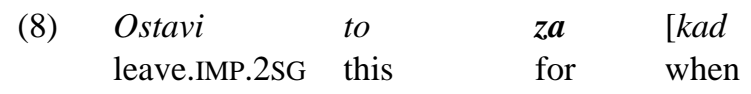

'Leave this to when you'll be seven years old'

$\begin{array}{lll}\text { budeš } & \text { imao } & 7 \\ \text { AUX.FUT.2SG } & \text { have.PST.PTCP.M } & \text { seven }\end{array}$

godina]

year.ACC.PL

(9) Je suis nostalgique de [quand ils étaient tout petits].

I be.1SG nostalgic of when they be.PST.3PL all small.PL

'I miss the time when they were only small kids'

(French)

(10)
[Pendant qu' $\quad$ elle
lit],
je regarde
read.PRS.3sG I watch.PRs.1sG the.F TV
télé
'While she reads, I watch TV'

(Spanish)

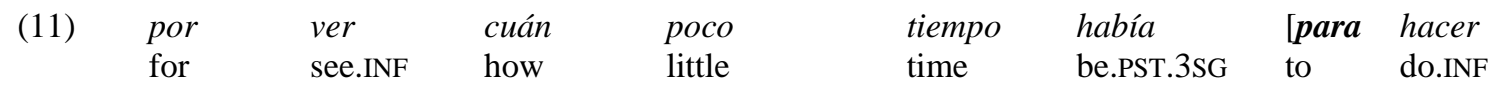




\begin{tabular}{|c|c|c|c|c|c|c|c|}
\hline $\begin{array}{l}\text { la } \\
\text { the }\end{array}$ & $\begin{array}{l}\text { experiencia] } \\
\text { experiment }\end{array}$ & $\begin{array}{l}\text { no } \\
\text { NEG }\end{array}$ & $\begin{array}{l}\text { quiso } \\
\text { want.PST.3SG }\end{array}$ & $\begin{array}{l}\text { decirle } \\
\text { tell.INF.CL }\end{array}$ & $\begin{array}{l}\text { otra } \\
\text { other }\end{array}$ & $\begin{array}{l}\cos a \\
\text { thing }\end{array}$ & $\begin{array}{l}\text { sino } \\
\text { than }\end{array}$ \\
\hline le & agradecía & el & haberle & descubierto & $\tan$ & gran & secreto \\
\hline him.DAT & please.PST.3sG & the & have.INF.CL & discover.PST.PTCP & so & great & secret \\
\hline
\end{tabular}

In some theoretical frameworks (see e.g. Dubinsky \& Williams 1995), it is accepted that pendant and para in (9-10) may introduce (finite and non-finite) subordinate clauses. In more traditional syntactic approaches, however, pendant (que) and para in the examples above are analyzed as subordinators or conjunctions.

\subsection{Head \& argument relations}

In the traditional syntactic view, an adposition is usually attributed the morphosyntactic property of case assignment; this property motivates the concept of adpositional phrase in the first place. As head of an adpositional phrase, adpositions assign (usually nonnominative) case to the noun phrase which serves as complement of the adposition.

Adpositional phrases may be integrated into the more global structure of the clause in different ways. Thus, Melis (2003: 26-33) speaks of the "integrating” role of prepositions (hence, adpositions in general) and captures mechanisms behind incorporating adpositional phrase [R B] into [A] by distinguishing three possible "integration modes":

i) syntactic-semantic, typical of sentence adjuncts (12), (18-21); in this case, adpositional phrases can be seen as elements which display relatively strong semantic content and are syntactically relatively independent elements of the clause,

ii) lexical, characteristic of strong lexical selection (13); in this case, the adpositional phrase is semantically and syntactically dependent on some other element of the clause, most often the verb (in terms of valency relations);

iii) structural, when adpositional phrases serve to express grammatical relations and are very strongly integrated into phrases (and hence, into the clause) (14-16).

(French) $\begin{array}{llllll}\text { [Selon } & \text { la } & \text { météo], } & \text { les } & \text { averses } & \text { violentes perturberont } \\ \text { according.to } & \text { the.F.SG } & \text { weather.forecast } & \text { the.PL } & \text { rainfall.PL } & \text { violent.PL disrupt.FUT.3PL }\end{array}$

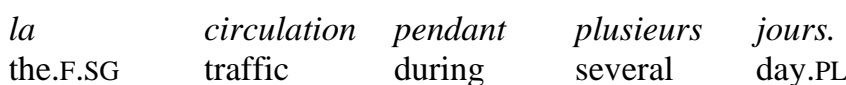
'According to the weather forecast, heavy rainfall will disrupt traffic for a few more days' (Melis 2003: 27) 
(Portuguese)

(14) A

coitada $\quad[$ da

Maria]!

the.F.SG

poor.F.SG

of.the.F.SG

Maria

'Poor Maria!'

(15) la ville [de Paris] est

la capitale de la

France

the.F.SGcity of Paris be.PRS.3SG the capital of the.F.SG France

'The city of Paris is the capital of France'

(French)

(16) J' ai le mal [de mer $]$
I have.PRs.1sG the sicknessof sea
'I suffer from sea sickness'

The relationships established by adpositions thus range from purely grammatical ones as in (1416) to others that are less semantically bleached, such as the agentive relationship in (17) and to a whole range of semantic relations. Some of the more frequent are spatial (1, 5-6), causal (3), temporal (18), instrumental (19-20), purposive (21) ones:

(Serbian)

(17)

$\begin{array}{llrlll}\text { Bio } & \text { je } & \text { izgrdjen } & {[\text { od }} & \text { svih } & \text { prisutnih }] \\ \text { be.PST.PTCP AUX.3SG } & \text { blamed } & \text { by } & \text { all.PL } & \text { present.PL } \\ \text { 'he was blamed by all persons present' } & & & \end{array}$

'he was blamed by all persons present'

(Polish)

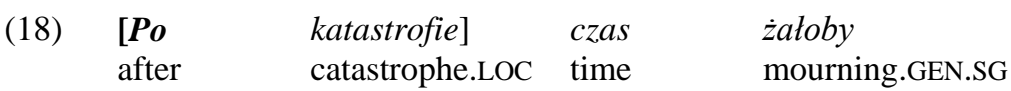

'After the catastrophe has come the time of mourning' (Gazeta Wyborcza, March 25 $5^{\text {th }}$ 2015)

(19) Connectez- vous $[\grave{a}$ l'aide de votre adresse électronique] connect.IMP.PRS.2PL you with your address e-mail

'Log in with your e-mail address'

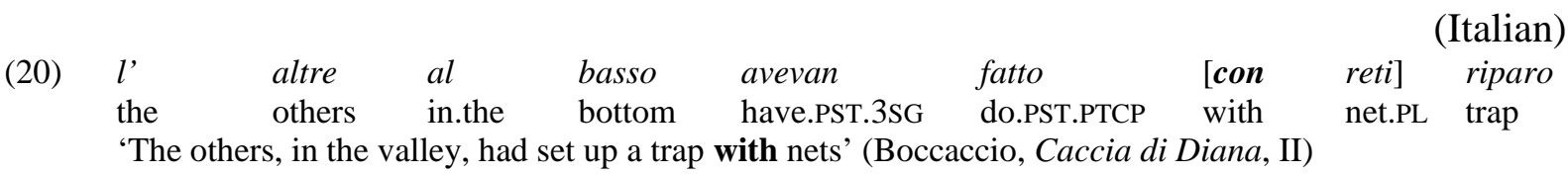

(German)

$\begin{array}{llllll}\text { (21) Wir } \quad \text { kämpfen } \quad[\text { für } & \text { eine } & \text { bessere } & \text { Zukunft }] \\ \text { we fight.PRs.1PL for } & \text { a.F } & \text { better.F.ACC.SG } & \text { future } \\ \text { 'We are fighting for a better future' } & & & \end{array}$


Depending on whether the relationship established is seen as prominently grammatical/structural or lexical/semantic, some scholars distinguish between functional and lexical adpositions (see Gougenheim 1950, 1959, Spang-Hansen 1953, Lehmann 1985, Svorou 1994); it is also possible to distinguish a third class of semi-lexical adpositions (see e.g. Mardale 2011). In short, there seems to be a continuum between the two classes, with many elements in between.

The former, i.e. structural or functional adpositions, generally correspond to a very small set of short, simple, but very frequent (and often highly polysemous) forms (see 22-23), while the latter, i.e. lexical adpositions, are generally taken to include a wider range of both formally simple (24) and complex (25) expressions:

(French)

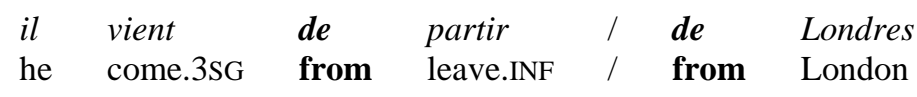

'he just left / he comes from London'

(French)

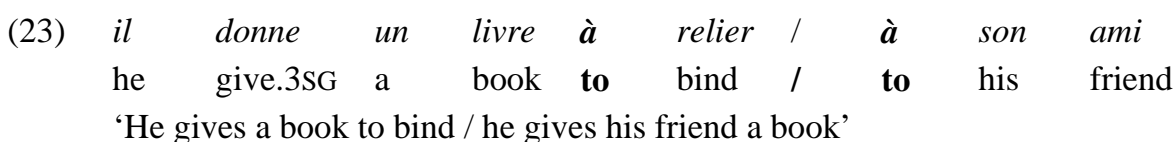

(English)

(24) he came after us

(English)

(25) she parked in front of the movie theater

An important subclass of adpositions are complex adpositions (CAs), which may be roughly defined as multi-word linguistic expressions which serve typical functions of adpositions, and which can be shown to alternate with them. Complex adpositions pertain to the subclass of lexical adpositions, with relatively rich and specific semantics.

\section{Complex adpositions: a descriptive approach}

Concerning complex adpositions, there is to our knowledge no equivalent of the existing typological overviews on simple adpositions (e.g. Zelinsky-Wibbelt 1993, Svorou 1994, Hagège 2010). However, there have been a number of studies on individual languages, as noted above. Some mentions in passing are found in books on simple adpositions (e.g. Melis 2003, Kurzon \& Adler 2008), and a few books provide an overview of complex adpositions in a given language (Cifuentes Honrubia 2003, Hoffmann 2005, Jürine 2016). A number of papers bear on specific questions related to complex adpositions (Lehmann 1985, Leeman 
2007, 2008, Gross 2006, Fagard \& De Mulder 2007, Piunno \& Ganfi 2017), as well as a recent special issue of the Revue Romane (Fagard, Lima \& Stosic (eds.) 2019a).

This body of literature broadly confirms expectations, which could be summarized as follows.

a) CAs are hard to define, because there is a continuum from syntactically free to fixed expressions (see already, on this subject, Borillo 1991, 1997, Seppänen et al. 1994, Melis 2003);

b) there are doubts as to what exactly happens during the evolution from one to the other, and which has been described as lexicalization, grammaticalization and constructionalization (cf. Hoffmann 2004);

c) while some languages or language strata display a wealth of constructions, others seem to have very limited paradigms ${ }^{1}$;

d) some syntactic patterns or construction types seem more productive and pervasive than others, and many authors actually only look at these more salient constructions, the most notable being $\left[\mathrm{P}_{1}\right.$ (Det) $\left.\mathrm{NP}_{2}\right]$ (see e.g. Huddleston 1984: 341-345);

e) the distributional equivalence between simple and complex adpositions is true only of so-called lexical adpositions (Fagard 2012),

f) CAs seem to have evolved in a mostly parallel fashion across European languages, suggesting the possibility of an areal phenomenon (Hüning 2014).

Complex adpositions, which could be described as less grammaticalized members of the overall category of adpositions, function in the language as adpositional units, though they are recognized as evincing some internal complexity, on account of surface structure (they are multi-word expressions, see (26-29)) and internal variation (for instance, in (26), au mépris de could be changed to au plus grand mépris de 'to the (lit.) greatest spite of'). It thus appears that complex adpositions are morphemic sequences in which some internal structure can be discerned, but whose elements dispose of reduced autonomy, both with respect to the syntagmatic and the paradigmatic aspects (cf. Heine 1989). In discourse, these elements often occur together as a unit. Semantically, the meaning of the whole sequence is autonomous and mostly noncompositional.

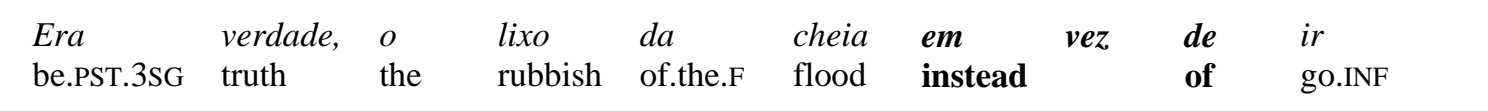
$\begin{array}{lllllll}\text { para } & a & \text { direita } & \text { ia } & \text { para } & a & \text { esquerda. } \\ \text { towards } & \text { the.F } & \text { right } & \text { go.PST.3SG } & \text { towards } & \text { the.F } & \text { left }\end{array}$ 'It was true, the debris of the flood instead of going right went left' (Eça de Queirós, Alves)

(French)
(27)
Menant dès
ce soir
même, au
mépris de ses
lois,

\footnotetext{
${ }^{1}$ This could be linked to different choices in definition, whence the need for this volume. However, the different chapters seem to confirm this trend, which is also clear in diachrony (see e.g. Fagard, to appear).
} 
take.GER from this evening self at.the spite of DET.POSS.PL laws

ses compagnes danser autour de sa statue

DET.POSS.PL companion.F.PL dance.INF around of DET.POSS.F.3sG statue

'Taking that same evening, despite his laws, her companions to dance around his statue' (Jean de La

Fontaine, Fables)

(English)

(28) the Board has responded to the government with regard to the pensions issue (BNC corpus)

(29)

Der

$\mathrm{Bau}$

wurde

aufgrund von

Streitigkeiten

the.NOM.M.SG

construction

AUX.PASS

on.the.basis of

conflicts

zwischen der

Stadt

Hamburg

und dem

Bauträger

Hochtief

between the.GEN.F.SG city

Hamburg

and

the.DAT.M.SG developer

Hochtief

in den

vergangenen

Jahren

immer

wieder

verschoben.

in the.DAT.N.PL past year.DAT.PL ever again delay.PST.PTCP

'The construction was repeatedly delayed in the past years on account of disputes between the city of Hamburg and the promoter.' (Süddeutsche Zeitung, January $18^{\text {th }}$, 2015)

Which linguistic expressions qualify as complex adpositions in a particular language, and on which grounds, is still a matter of considerable debate. Moreover, the status of the category 'complex adpositions', applying to pre- and postpositions equally, is not entirely clear.

Although the category is commonly accepted nowadays (in the tradition of Quirk et al., 1985), it is still resisted by some researchers, who basically deem such items to be equivalent to adnominal or nominal groups that have a certain degree of idiomaticity (Huddleston \& Pullum, 2002). In order to deal with complex adpositions in a cross-linguistic and typological perspective, as we have tried to do in this book, we felt the need of a common working definition of this sub-class of expressions.

\section{Working definitions: Adpositions and nominal relators}

In this section, we propose a general definition of the category of complex adpositions, including complex adnominal relators. The definition is thus operational both for languages with adpositions and for languages with other types of nominal relators, such as case-marking and relational nouns.

\subsection{Simple nominal relators}

It is commonly accepted that a construction such as (Fr) à cause de 'because of (lit. at cause of)' is a complex adposition. But what does that mean exactly? Are complex adpositions very different from simple ones? How does one identify a complex adposition? Is it a homogeneous subclass of adpositions, or a different word class altogether, or neither? In order 
to look for answers to these questions, we believe it is fundamental to start out with a working definition of complex adpositions (and their distributional equivalents in languages with no adpositions), which itself requires, first, a working definition of simple adpositions and more generally of simple nominal relation markers or relators.

Simple relators: In many languages, basic nominal relation markers (i.e. relation markers which prototypically introduce nouns or noun phrases), which we call here relators, are CASE MARKERS and ADPOSITIONS;

1) these two are well-known categories, rather well identified, with wide typological variation (in number of items per language, semantics, formal complexity, etc.)

2) they are SIMPLE relators, i.e. they consist of one morpheme or lexeme: (Fr) à 'at', devant 'in front of', sur 'on', (Eng) on, in, (Sp) ante 'in front of', tras 'behind'...; this is also true of case markers, which generally consist of one or two morphemes at the most.

3) these simple relators have three distinct functions:

(at the syntactic level)

i. they introduce an a priori nominal constituent

ii. they establish a relation between this (lower) constituent and a (higher) constituent

(at the semantic level)

iii. they help determine the semantic nature of this relationship. ${ }^{2}$

4) SIMPLE RELATORS sometimes grammaticalize further, the result being their decategorialization (Hopper \& Traugott 1993, Heine 2003). Simple adpositions can come to be used as determiners, complementizers, agent markers in passive constructions, and finally case makers, as noted by Lehmann (1985):

i. determiner: (Fr) de l'eau 'some water (lit. of the water)'

ii. complementizer: (Eng) I would like to visit London

iii. linking element: $(\mathrm{Gm})$ Zeitungsleser 'newspaper reader (lit.

${ }^{2}$ In the examples below, the adpositions (i) introduce constituents (respectively la maison, neuf heures, dinner, the judge, ścieżka, las), (ii) establish a relation between these constituents and a higher constituent (respectively (il) rentre, (he) came over, (he) stood, wrócilismy), and (iii) determine the semantic nature of this relationship - in these examples, with various spatial or temporal meanings, which are in part determined by the context itself.

(a) (Fr) il rentre à la maison 'he goes home (lit. he comes.back to the house)'

(b) (Fr) il rentre à neuf heures 'he comes back at nine o'clock'

(c) (Eng) he came over before dinner

(d) (Eng) he stood before the judge

(e) (Pol) wróciliśmy ścieżka / przez las come.back.PST.1PL.M path.INSTR through wood.ACC

'we came back following the path / through the woods'

The semantic relations expressed by adpositions are wide-ranging, from spatial (e.g. topological and functional relations, see Vandeloise 1986, Svorou 1994) to temporal (e.g. antecedence, etc., see Haspelmath 1997) and abstract relations (e.g. cause, concession, purpose, agentivity, etc.). 
newspaper.LINKING_S.reader)', (Eng) yesterday's paper

These four features can be considered as definitional criteria for identifying simple nominal relators.

\subsection{Complex nominal relators}

Complex relators: Many languages have another type of nominal relators, which are not formally simple but COMPLEX;

1) a COMPLEX RELATOR is functionally equivalent to a simple one, but is MORPHOLOGICALLY complex; ${ }^{3}$

2) COMPLEX RELATORS have the same three distinct functions as simple relators; however, these three functions can (but need not) be performed by different components of the complex relator; typically:

i. a simple adposition (or case marker) marks the link with the lower constituent

ii. another simple adposition (or case marker) establishes the relation with the higher constituent

iii. a lexical nucleus (typically nominal) determines the semantic nature of the relation

\begin{tabular}{|c|c|c|c|}
\hline Language & $\begin{array}{c}\text { simple adposition / } \\
\text { case marker }\end{array}$ & lexical nucleus & $\begin{array}{c}\text { simple adposition/ } \\
\text { case marker }\end{array}$ \\
\hline German & in & Richtung & auf \\
\hline Serbian & $u$ & pravcu & GEN \\
\hline
\end{tabular}

In examples such as (Gm) in Richtung auf 'toward (lit. in the direction of)' or (Sb) u pravcu 'in relation to', the simple adpositions ( auf 'on, to') and the genitive case perform functions (i), and (ii) (in 'in', $u$ 'in'), while the lexical nucleus (Richtung 'direction', pravac 'direction') determines the semantic nature of the relation.

3) a COMPLEX RELATOR is semantically more specific. In comparison, SIMPLE RELATORS tend to be semantically bleached and therefore seem much more polysemous.

There appears to be some sort of semantic equivalence between simple and complex relators, but complex relators typically appear in more restricted contexts, due to their higher lexical specification as in (30-32).

(30) For / with respect to your book, he said it was okay.

(31) For (/*With respect to) twenty years, I've lived here

(32) He came for (/*with respect to) your book.

\footnotetext{
${ }^{3}$ This complexity is variable, in part because there is a diachronic tendency to routinization and fusion and/or shedding of the various elements through lexicalization and eventually grammaticalization.
} 
4) COMPLEX RELATORS, unlike SIMPLE RELATORS, do not seem to have other uses than adpositional, except maybe for uses as complementizers, e.g. (Pt) a fim de 'in order to', apesar de 'despite’.

The distinction between simple and complex relators is not clear-cut, however. This is because, diachronically, simple relators typically result from the grammaticalization of complex relators. There are different scenarios of simplification, with e.g. univerbation and agglutination (cf. Lehmann 2015: 160-162), namely:

i. $\quad$ shedding of elements, e.g. (Gm) in Richtung von > Richtung von > Richtung 'towards (lit. in the direction of)', (Fr) du côté de > du côté > côté, en face de $>$ en face 'in front of' ${ }^{4},(\mathrm{Pt})$ em frente $a>$ frente a 'in front of'.

ii. morphological and/or phonological fusion of grammatical and lexical elements, e.g. (Eng) in stead of > instead of, (Gm) an Hand von > anhand von 'by means of (lit. at the hands of)'.

iii. a mixture of the two, e.g. (Gm) an Statt > anstatt $>$ statt 'instead of'.

\section{Research questions}

Although there has been, in the last years, an increase in the interest on complex adpositions, the field is in our view still vastly understudied. One reason is the lack of encompassing studies, bringing together results of this increasing body of descriptive research on the topic in various languages. Accordingly, many questions remain unanswered. Among the variety of topics open to exploration, this book aims to bring some answers to a few questions, which we describe in some detail below.

\section{DEFINITION AND CATEGORICAL STATUS OF CAS}

The first question is naturally that of the definition of the class 'complex adpositions'. Complex adpositions are a polemic category, inasmuch as not even their definition is consensual. Sequences such as (Eng.) instead of or in order to, or (Germ.) aufgrund von (+ GEN) are usually considered as complex prepositions, mainly due to their complex internal structure and to their relational function. However, the very definition of a complex adposition is a matter of debate, as shown e.g. by the different positions of two reference grammars of English. While Quirk et al. (1985) consider that there is justification for such a category, Huddleston \& Pullum (2002) dismiss the concept on the basis of the syntactic properties of these sequences, although acknowledging their semantic autonomy (see also Seppänen et al.

\footnotetext{
${ }^{4}$ The adpositional use of en face is non standard, but attested (i), at least since the $19^{\text {th }}$ century (ii).

(i) bar de la Renaissance (en face la poste) 'bar la Renaissance (across from the post office)' (FrTenTen)

(ii) un appartement splendide en face le parc Monceau 'a splendid flat across from the parc Monceau' (Goncourt, Journal, II, p. 105; GGHF corpus).

${ }^{5}$ This fusion is not always reflected in spelling, as in (Fr) à travers, which should be analyzed as a simple adposition [à_travers]: in examples such as elle l'a jeté à travers la fenêtre 'she through it/him through the window', nothing whatsoever can be inserted between $a ̀$ and travers.
} 
1994). German reference grammars, on the other hand, admit several subcategories of adpositions, i.e. simple, complex, and 'secondary' ${ }^{6}$ ones (e.g., trotz, kraft, laut, etc.), which are distinguished on the basis of some prototypical features, including the transparency as to their lexical sources (Diewald 1997, 65-73).

What criteria are more relevant for the class of CAs and to which extent are they dependent on the internal structure of CAs? For CPs, some have been proposed in the literature (Quirk et al. 1985, Seppänen et al. 1994, Borillo 1997, 2001, Adler 2001, Cifuentes Honrubia 2003, Fagard 2006, Leeman 2007) but no cluster of criteria seems consensual. Also, as research widens from concern with prepositions to concern with adpositions, criteria may be in need of revision. Comparing the system of adpositions in a series of more or less genetically and/or areally related languages is a plausible way of improving the existing criteria and definition.

\section{GRAMMATICALIZATION, LEXICALIZATION AND CONSTRUCTIONALIZATION}

Definitional uncertainty, however, has not prevented a certain consensus about the kind of grammaticalization and/or lexicalization processes that complex adpositions undergo. This concerns at least those CAs with the most common source structures, such as $\left[\mathrm{P}_{1}(+\mathrm{Det})+\mathrm{N}+\mathrm{P}_{2}\right]$ (see e.g. (26-27) above; see Fagard \& De Mulder, 2007). These processes can be dealt within the framework of Lehmann's (2015) grammaticalization parameters: e.g., the change of $\mathrm{P}_{1}$ from paradigmatic variability to invariability, the impossibility of including linguistic material between $\mathrm{P}_{1}\left(+\right.$ Det) and $\mathrm{N}$, and the eventual coalescence of $\mathrm{P}_{1}(+$ Det $)+\mathrm{N}$. However, many other grammaticalization (or lexicalization) paths need to be explored. Related to this is the issue of whether a regular order can be discerned in the processes of grammaticalization leading to the emergence of a member of one of these classes from a member of one of the others. For instance, the relation between CAs and closely related categories such as adverbs and conjunctions should be explored: while it seems reasonable to assume that grammaticalization processes involving adverbs, simple adpositions and conjunctions are unidirectional (Adverb > Adposition > Conjunction), is it possible to say the same about complex adpositions? And how do these processes fare under the unidirectionality hypothesis (Hopper \& Traugott 2003)?

How do frequency and degree of a CA's grammaticalization correlate? It is generally assumed in grammaticalization studies, as well as in usage-based theories (Bybee 2010), that higher type frequency correlates with a more advanced stage of grammaticalization. Many studies on CAs provide evidence for this hypothesis (e.g. Hoffmann 2005, Lima 2014, Stosic 2012), but more empirical studies are necessary.

\section{MORPHOLOGICAL AND SYNTACTIC PATTERNS OF CAS}

The determination of subcategories of CAs - which may reflect different stages in grammaticalization - should be discussed (see Adler's 2008 distinction of compound prepositions and prepositional locutions).

\footnotetext{
${ }^{6}$ This term has also widely been used by Slavic grammarians and linguists since the beginning of the $20^{\text {th }}$ century, as opposed to "primitive” adpositions (see, among others, Hill 2012).
} 
Compiling inventories of structural types of CAs in European languages is central for a deeper understanding of their adpositional systems. Complex adpositions may have their origin in a great variety of syntactically as well as morphologically complex structures: besides [ $\mathrm{P}_{1}$ (Det) $\left.\mathrm{NP}_{2}\right]$, we can find $\left[\mathrm{P}_{1} \mathrm{AdvP}_{2}\right]$ (Fr. en dehors de 'outside, except'), $\left[\mathrm{P}_{1} \mathrm{P}_{2}\right]$ (Sp. para con 'towards, for'), [РтсРP] (Pt. devido a 'owing to, on account of'), [AdjP] (Eng. due to), [NP] (Pt. face $a$ 'in front of, given, in the face of'), [P+N] (Ger. mithilfe 'by means of, by dint of, thanks to'), [VP] (Sp. pese a 'despite'), etc. Do European languages share some of these schemas of CAs, and if so to which extent?

Related to this is the issue of productivity of CAs source structures. Some structures - such as $\left[\mathrm{P}_{1}(\mathrm{DET}) \mathrm{NP}_{2}\right]$ - seem to be highly productive and regular, while others seem to emerge ad hoc and have just a few members. Is the emergence of CAs always casual or are there patterns of productivity? What differences can be observed cross-linguistically regarding the productivity of structural patterns?

\section{EMERGENCE AND EVOLUTION OF CAS IN EUROPEAN LANGUAGES}

In studies on grammaticalization, the need is felt for a deeper understanding of the processes that lead to the emergence of complex adpositions, as well as to their evolution and possible change into simple adpositions and into case markers. The main aim of the present volume is to look for new insights into these problems in the domain of European languages. Thus, we bring together contributions from a varied array of European languages, so that a good picture of the different realities involving the emergence and the evolution of CAs may ensue. The background for these studies has been laid out in interesting work relating to complex prepositions and/or their grammaticalization, on the one hand (Lindqvist 1994, Schwenter and Traugott 1995, Di Meola 2000, Cifuentes Honrubia 2003, Hoffmann 2005, among others), and to adpositions on the other (as, e.g., Kurzon \& Adler 2008, Hagège 2010, Libert 2013). We aim at widening the object under analysis from the traditional one of complex prepositions to the more embracing one of complex adpositions, thus gaining the advantage of contemplating studies on complex postpositions (and circumpositions), which have been so far neglected, at least as far as their grammaticalization and/or lexicalization are concerned.

\section{Layout of the book}

\subsection{Complex adpositions in Romance Languages}

In the chapter "Complex adpositions in Romance Languages”, Benjamin Fagard, Dejan Stosic and José Pinto de Lima describe the systems of complex adpositions in modern Romance languages. One obvious question with respect to complex adpositions is that of their status: are they simply a morphosyntactically complex variant of simple adpositions? How should they be defined? There have been a few studies on complex adpositions in individual Romance languages (for instance Spanish, Cifuentes Honrubia 2003, or Portuguese, Lima 2014, 2019a, 2019b), and a few papers on complex adpositions in Romance languages in general (for instance Fagard \& Mardale 2007), there is still much to say. With a corpus-based analysis focusing on three Romance languages, French, Portuguese and Romanian, the authors show that some features of complex adpositions are common to most if not all 
varieties, while some seem to be specificities of one or more Romance language(s). One case in point is the way such constructions can be tested (see Adler 2001, 2008), for instance with possessives - a test which does not seem to affect French and Portuguese (Catalan, etc.) CAs in the same way. The clear contrast which appears in French between non-lexicalized constructions and CAs on account of their intolerance of the possessive (à la place de Jean 'in John's seat (or place)' $\rightarrow$ à sa place 'instead of John'; au lieu de Jean $\rightarrow$ *à son lieu 'in John's stead') is not found in Portuguese. In Portuguese, CAs do not exhibit this particularity, or at least to a lesser extent: por causa do João and por sua causa 'because of John/of him' are both possible, as is em seu lugar 'in his stead', etc.). They go on to formulate a hypothesis as to the development of CAs in various Romance languages, suggesting it may not have been parallel.

\subsection{Complex Adpositions in West-Germanic Languages}

In the chapter "Complex Adpositions in West-Germanic Languages", Matthias Hüning, Elena Smirnova and Anatol Stefanowitsch provide an overview of simple and complex adpositions in West-Germanic languages, focusing particularly on Dutch, German, and English. They show that the class of prepositions is not a closed class in these languages, and in Germanic languages in general, and that there are several possibilities to extend this class.

The chapter provides a comprehensive description of the inventories of simple and complex adpositions in the three languages and attempts at their systematization in terms of morphosyntactic features, semantics, and patterns of formation. With respect to the diachrony of the complex adpositions in West-Germanic languages, the chapter proposes a unified account of their emergence and development in terms of grammaticalization and constructionalization. The focus of this chapter is on structural and diachronic aspects of so called PNP-constructions (i.e. the structural pattern 'preposition - noun - preposition') like Nl. met betrekking tot - G. in Bezug auf - Eng. with regard to, constructions that are very productive today.

\subsection{Complex adpositions in Slavic languages: the case of Serbian}

In the chapter "Complex adpositions in Slavic languages: the case of Serbian”, Dejan Stosic describes the main morphological, syntactic and semantic features of the prepositional system of Serbian, a Slavic language, mostly in a synchronic perspective. He provides a morphosyntactic survey of inventories of simple and complex prepositions in Serbian roughly 100 simple prepositions (see Mrazović 2009) and more than 400 complex ones. The most frequent morphosyntactic pattern of formation of complex adpositions is similar to the one found in other European languages, involving a noun preceded by one relator and followed by another, i.e. [Prep Noun + GEN], but other oblique cases can also appear as second relator. In many cases the second relator corresponds to a preposition. Unlike simple adpositions, which generally select more than one case, complex adpositions show a very strict selection, limited to only one case. As for the evolution of Serbian complex adpositions, preliminary results of the corpus study suggest that this pattern of grammaticalization becomes especially widespread starting from the $15^{\text {th }}$ century. 


\subsection{Prepositions in Brythonic Celtic: Stability and Contact-Induced Change}

In the chapter "Prepositions in Brythonic Celtic: Stability and Contact-Induced Change", Kevin Rottet reports on the use of simple and complex adpositions in Brythonic Celtic. Prepositions represent a significant part of what is distinctive about the Celtic languages. Many prepositions trigger initial consonant mutations (Breizh 'Brittany' but da Vreizh 'to Brittany'); simple prepositions are 'conjugated' for pronominal complements (evit ma breur 'for my brother' but evitañ 'for him'). There are several patterns of complex prepositions including one in which pronominal complements take the form of possessive infixes (a-raok 'before' but en ho raok 'before you', cf. ho 'your'). Additionally, language contact, with English (in the case of Welsh) and French (where Breton is concerned) has played a role in recent times. For instance, Breton expressions for 'up' and 'down' (d'al laez 'to the top', d'an traoñ 'to the base') are only weakly grammaticalized whereas in Welsh, i fyny 'to a mountain' and $i$ lawr 'to a floor' are highly grammaticalized and have undergone nearly total interlingual identification with the English words up and down, becoming full-fledged prepositions (and not just adverbs), and even competing with the traditional pattern of phrases of bodily posture, e.g. the contact-induced eistedd i lawr 'to sit down' versus the traditional mynd ar ei eistedd lit. 'to go on his sitting'.

\subsection{Greek complex adpositions as a key to Greek adpositional development}

In the chapter "Greek complex adpositions as a key to Greek adpositional development", Pietro Bortone describes the adpositional system of Modern Greek. In Greek, a whole system of adpositions - appearing, initially, both before and after nouns - can be observed coming into existence (in combination with an older case system), then fading and being renewed. The use of multiple adposition+case combinations ([P1+case1], [P1+case2], etc.) was slowly abandoned, but new combinations of adverbs with old adpositions ([ADV1+P1], [ADV1+P2]) enabled the system to express lost semantic nuances. The strikingly rich Ancient Greek adpositional inventory was thus gradually replaced and diversified largely thanks to the use of compounds - which have become the norm in Modern Greek. Furthermore, in Modern Greek, a number of phrases distributionally comparable to prototypical adpositions are also in use. These can express meanings that Greek previously expressed with simple adpositions. One may therefore ask whether such Greek phrases, which are an open class, could be considered fully-fledged adpositions and, ultimately, where the boundaries of the 'adposition' category should be drawn. Those Greek phrases, after all, match constructions that are found in other modern European languages, and which some linguists want to classify as adpositions (e.g. 'according to', 'at the time of', 'at the presence of', 'on the theme of', 'for the benefit of', 'under the power of'). This fact highlights also the elusive possibility that their use in Greek might be, in part, a contact-induced change.

\subsection{Complex Prepositions in Albanian: a first assessment}

In the chapter "Complex Prepositions in Albanian: a first assessment", Guillaume Bonnet and Benjamin Fagard investigate the marking of nominal relations in Albanian. They describe the use and importance of case marking and simple prepositions, and go on to investigate the existence and use of complex prepositions, on the basis of the (limited) literature and of a corpus study. Relying on two corpora, the Albanian National Corpus (ANC) and the parallel corpus OPUS, totaling 20 and 46 million words respectively, the authors provide frequency lists and distributional features of all simple prepositions as well as a list of sequences which 
could be analyzed as complex prepositions. This makes it possible for the authors to account for the formal and functional differences between different types of simple and complex adpositions. The authors also address the question of the possible origin of CAs in Albanian, showing a possible effect of language contact.

\subsection{Recycling grammar - development of (complex) adpositions in Estonian}

In the chapter "Recycling grammar - development of (complex) adpositions in Estonian", Anni Jürine provides an overview of complex adpositions (CAs) in Estonian, with a special focus on complex postpositions (CPs). The development of CPs is here viewed as an instance of recycling grammar - a phenomenon whereby new complex grammatical items develop as lexical and grammatical components merge (see Jürine \& Habicht 2013, 2017).

Most Estonian postpositions are simple postpositions, and the author shows that the development of CPs in Estonian is a process which is still in its early stages and has so far received very little attention. Indeed, until quite recently (Veismann \& Erelt 2017) the (sub)category was not found in grammars.

CPs in Estonian include two components - a noun and a simple postposition. According to Jürine (2016), who has investigated body part related complex postpositions, CPs in Estonian have the following characteristics: unit interpretation, desemanticization, decategorialization, and extension to new contexts. These features, which are listed also in many other accounts of CAs (e.g. Hoffmann 2005, Lehmann 2002, Villada Moirón \& Bouma 2003, Adler 2008), may be used as criteria to distinguish Estonian CPs from their source form. Most CPs have both readings in contemporary Estonian. As such, the development of CPs is part of a developmental cycle of function words in Estonian where new grammatical items are formed by simple grams merging with lexical items:

$$
\begin{array}{ll}
\text { NOUN + LOC. CASE SUFFIX } & >\text { SIMPLE POSTPOSITION } \\
\text { NOUN + SIMPLE POSTPOSITION }> & \text { COMPLEX POSTPOSITION }
\end{array}
$$

As there are many parallels in the development of complex and simple postpositions, the author observes the development of CPs against the backdrop of functional and formal properties of simple postpositions in Estonian. The investigation is carried out synchronically as well as diachronically.

\subsection{Complex adpositions in Permic languages}

In the chapter "Complex adpositions in Permic languages”, Timofey Arkhangelskiy and Maria Usacheva provide an overview of nominal relations in Permic languages. Just as other Uralic languages, Permic languages have postpositions and no prepositions. Complex postpositions are very rare in Permic languages. The probable reason for this is that usually the postpositions are quickly agglutinated into complex case markers instead of existing as postpositional clusters. Besides, Permic spatial systems are quite complex: they include spatial cases (up to 8 in Udmurt, up to 9 in Komi, depending on the variety), postpositions with adverbial-like properties, and relational nouns (inflected postpositions) with noun-like properties. Yazva Komi also has a very developed system of deictic units which are often used instead of spatial PPs. However, some complex postpositions do exist. They consist of elements denoting 'front', 'back', 'bottom', 'top', 'side' in Udmurt; 'front', 'top', 'edge', 
'upper part' in Komi. Most of complex postpositions arise from PPs with the head with the meaning ‘side’ (Udmurt) or 'edge’ (Komi). In Yazva Komi there are relational nouns derived from complex postpositions which consisted of two stems: vardśl 'upper part' ( $\leftarrow$ v $\Lambda 1$ 'top' + $\mathrm{d} \Lambda \mathrm{r}$ 'edge') and urdól 'lower part' ( $\leftarrow$ ul 'bottom' $+\mathrm{d} \Lambda \mathrm{r}$ 'edge'). Permic complex postpositions are similar to simple spatial relational nouns in many respects. In Udmurt, they attach nominal dependents in the nominative or in the genitive, like both full-fledged and relational nouns. Unlike full-fledged nouns and like relational nouns, they allow for nominative dependents with definite referential status. However, they only accept pronominal dependents in the genitive, which puts them one step lower on the grammaticalization path than 'true' relational nouns. In Komi, complex postpositions attach dependents only in the nominative.

\subsection{Case marking and complex adpositions in Basque}

In the chapter "Case marking and complex adpositions in Basque", Gerd Jendraschek shows that Basque, a language isolate, widely differs from its neighbors with respect to nominal relators, having an elaborate inventory of case marking suffixes. The combination of a postposition with a bare nominal complement is rare, as postpositions typically govern a case, typically the genitive, although the dative, locative, ablative, and instrumental are also found. Some postpositions are invariable, for example arabera 'according to' (also used without a complement like an adverb). Many postpositional phrases are of the structure [N GEN Nrel case], where Nrel stands for a relational noun such as aurre 'front' or barru 'inside', followed by one of the local cases. Postpositional complements with inanimate referents such as etxe 'house' can form a compound-like complex nominal with the relational noun, as in etxe aurre 'house front'. Adverbial phrases are routinely turned into adnominal modifiers by adding $-k o$, as in etxe aurreko parkea 'the park in front of the house' (without genitive marking of the complement etxe) or zure aldameneko mutila 'the boy next to you' (with the genitive marker re on the possessive pronoun zure 'your'). Just as there are intermediate cases between case suffix and postposition, there are genitive constructions that are not typically listed among the postpositions, even though they fulfil a similar function, such as ozeanoaren hondoan 'at the bottom of the ocean'. One criterion to distinguish complex postpositions from mere possessive constructions is modifiability of the head, as in ozeanoaren hondo sakonean 'at the deep bottom of the ocean'.

\subsection{Structure and origin of Turkish adpositions}

In the chapter "Structure and origin of Turkish adpositions", Gerd Jendraschek reports on the system of nominal relations in Turkish. Turkish is the main representative of the Turkic language family whose geographic distribution reaches from East Asia to the Balkans. The Turkic languages are possibly related to other languages in North-East Asia such as Mongolian, Korean, and Japanese, with which they are often grouped together as an Altaic or Trans-Eurasian macro-family. While such a genetic connection remains controversial, these languages share many typological features. Turkish morphosyntax is overwhelmingly headfinal and agglutinating, and as such it features a moderately elaborate system of five cases. 
These include three local cases, which are a conflated allative-dative, a locative, and an ablative case. A possible addition to the case paradigm is the comitative-instrumental postposition ile 'with', which in spoken language cliticizes to the noun. A particularity of Turkish are the simple postpositions governing an unmarked nominative with lexical nouns, but a genitive with pronouns. While a few postpositions are monomorphemic, Turkish has a large number of derived postpositions, such as gelince 'as for', a converb form of the stem gel 'come', or the ablative-governing postpositions önce 'before' and sonra 'after', likely derived from the nouns ön 'front' and son 'end', respectively. Certain compound-like noun phrases marked by a third-person possessive suffix on the head have been reinterpreted as adverbial adjuncts, turning the head noun into a postposition, as in anlaşma sonucu '(as a) result of the agreement' (from sonuç 'result') or kanun gereği 'according to the law' (from gerek 'necessity'). Local relations involving a spatial region have the pattern [N-GEN NrelPOSScase], where Nrel is a relational noun such as yan 'side' or üst 'top', followed by a local case indicating direction, position, or origin, e.g. masanın üstünden 'from the table top/surface' or perhaps 'from on the table', where masanın üstü 'the surface of the table' is followed by the ablative case suffix. As for diachrony, it is important to note that a considerable part of present-day Turkish vocabulary is the result of the language reform of the $20^{\text {th }}$ century, whose primary goal was the replacement of Arabic and Persian loanwords with deliberately coined neologisms. This also affected postpositions, where e.g. rağmen 'despite' of Arabic origin now coexists with karşın (based on karşı 'against').

\subsection{Compound prepositions in Maltese: PREP-PREP combinations and related issues}

In the chapter "Compound prepositions in Maltese: PREP-PREP combinations and related issues", Thomas Stolz provides an overview of complex prepositions in Maltese. He focuses on the formal and functional properties of certain subtypes of compound prepositions (COMPREPS) as attested in contemporary Maltese. The presentation of the Maltese evidence of COMPREPS shows a high degree of heterogeneity, to the point that it seems hardly possible to claim that there is only one candidate for the status of COMPREP in Maltese. On the contrary, several distinct types of COMPREPS emerge, their members sharing different subsets of properties with the canonical COMPREP. The diachronic developments are suggestive of gradual transitions from one class to the other. These transitions, in turn, presuppose that the domain of COMPREPS is organized like a continuum but not exclusively along the lines of the polar distinction transparent vs opaque. Univerbations result from processes which affect two different categories, namely PREP-PREP combinations and PPs. It is these two sources which occupy the opposing extremes of the continuum with univerbations being situated in the continuum's centre. The goal of the processes is the creation of new complex prepositional lexemes, which ultimately may be reanalyzed as monomorphic (i.e. unanalyzable) units and thus enrich the inventory of simple PREPS.

\subsection{Discussion: A (micro)typological approach to Language change - the case of nominal relators}

In this last chapter, the editors of the volume discuss the notion of complex nominal relator on the basis of the data presented in the previous chapters. They show that there is indeed 
considerable evidence pointing towards a specificity of complex nominal relators (CNRs), independently from language type, at least in European languages: whatever their basic 'relational' components - prepositions, postpositions, case markers, relational nouns - the definition put forward in the introduction seems to be valid for all languages taken in consideration. The importance of a diachronic approach is obvious for the study of CNRs, which show (by definition) functional affinities with simple nominal relators (SNRs) and seem to function as a reservoir, from which SNRs are 'pulled out' by further grammaticalization. The authors also discuss a few examples which seem to contradict this reservoir hypothesis, and propose a few lines of research for future studies.

\begin{tabular}{llll}
\multicolumn{2}{l}{ Abbreviations } & & \\
ACC & accusative & M & masculine \\
AUX & auxiliary & N & neuter \\
CL & clitic & NEG & negation \\
DAT & dative & NOM & nominative \\
DEI & deictic & PASS & passive \\
DEM & demonstrative & PL & plural \\
DET & determiner & POSS & possessive \\
F & feminine & PRO & pronoun \\
FUT & future & PRS & present \\
GEN & genitive & PST & past \\
GER & gerund & PTCP & participle \\
IMP & imperative & REL & relative \\
IND & indicative & SG & singular \\
INF & infinitive & SBJ & subjunctive \\
LOC & locative & &
\end{tabular}

\section{References}

Adler, Silvia. 2001. Les locutions prépositives : questions de méthodologie et de définition. Travaux de linguistique 42-43. 157-170.

Adler, Silvia. 2007. Locutions prépositives temporelles et modes d'anaphorisation. In David Trotter (ed.), Actes du XXIVe Congrès International de linguistique et Philologies Romanes, 495-508. Tübingen: Niemeyer.

Adler, Silvia. 2008. French compound prepositions, prepositional locutions and prepositional phrases in the scope of the absolute use. In Dennis Kurzon \& Silvia Adler (eds.), Adpositions: Pragmatic, semantic and syntactic perspectives, 17-35. Amsterdam \& Philadelphia: John Benjamins.

Anscombre, Jean-Claude. 2007. Les indicateurs aspectuels de déroulement processif : en cours de, en passe de, en train de, en voie de. Cahiers de lexicologie 90. 41-74.

Auroux, Sylvain. 1989-2000. Histoire des idées linguistiques. Liège: Mardaga.

Boissin, Henri. 1975. Grammaire de l'albanais moderne. Paris: Chez l'auteur.

Borillo, Andrée. 1991. Le lexique de l'espace : prépositions et locutions prépositionnelles de lieu en français. In Liliane Tasmowski \& Anne Zribi-Hertz (eds.), Hommage à Nicolas Ruwet, 176190.Gand: Communication \& Cognition.

Borillo, Andrée. 1997. Aide à l’identification des prépositions complexes de temps et de lieu. Faits de langue 9, 173-184. 
Borillo, Andrée. 2000. Degrés de grammaticalisation : des noms de partie aux prépositions spatiales. Travaux linguistiques du CERLICO 13. 257-274.

Borillo, Andrée. 2001. Il y a prépositions et prépositions. Travaux de linguistique 42-43. 141-155.

Bortone, Pietro. 2010. Greek prepositions - from antiquity to the present. Oxford: Oxford University Press.

Bree, Cor van. 2014. Adpositionele configuraties in het Nederlands. Acta Universitatis Wratislaviensis. Neerlandica Wratislaviensia 24. 11-25.

Brøndal, Viggo R. 1940. Prcpositionernes Theori - indledning til en rationel Betydningslere [Theory of prepositions - Introduction to a rational study of semantics]. Copenhagen: B. Lunos.

Brøndal, Viggo R. 1950. Théorie des prépositions. Introduction à une sémantique rationnelle. Copenhagen: E. Munksgaard.

Bybee, Joan. 2010. Language, usage and cognition. Cambridge: Cambridge University Press.

Căpățână, Cecilia. 2000. Locuțiunile prepoziționale [Complex prepositions]. In Doina Negomireanu (ed.), Ion Coteanu. In memoriam, 84-89. Craiova: Editura Universitaria.

Căpăţână, Cecilia. 2003. Locuțiunile prepoziționale [Complex prepositions]. Limba Română

[Romanian language] XIII(1). 48-53.

Casadei, Federica. 2001. Le locuzioni preposizionali. Struttura lessicale e gradi di lessicalizzazione. Lingua e Stile 36(1). 21-36.

Cifuentes Honrubia, José Luis. 2003. Locuciones prepositivas - sobre la gramaticalización preposicional en español. Alicante: Universidad de Alicante.

Ciobanu, Fulvia. 1957. Observații asupra prepozițiilor și locuțiunilor prepoziționale din limba română [Observations on prepositions and complex prepositions in Romanian]. Studii de gramatică [Grammar studies] 2. 357-388.

Comrie, Bernard, \& Greville G. Corbett (eds.). 1993. The Slavonic languages. London \& New York: Routledge.

Di Meola, Claudio. 2000. Die Grammatikalisierung deutscher Präpositionen (Studien Zur Deutschen Grammatik 62). Tübingen: Stauffenburg.

Diewald, Gabriele. 1997. Grammatikalisierung. Eine Einführung in Sein und Werden grammatischer Formen. Tübingen: Niemeyer.

Dubinsky, Stanley W., \& Kemp Williams. 1995. Recategorization of Prepositions as Complementizers: The Case of Temporal Prepositions in English. Linguistic Inquiry 26(1). 125137.

Fagard, Benjamin, \& Alexandru Mardale. 2007. Systèmes prépositionnels des langues romanes: la notion de partie du discours en diachronie. In David A. Trotter (ed.), Actes du XXIVe Congrès International de Linguistique et de Philologie Romanes, 91-104. Tübingen: Niemeyer.

Fagard, Benjamin, \& Alexandru Mardale. 2019. Les prépositions complexes du roumain - approche sur corpus. In Benjamin Fagard, José P. Lima, \& Dejan Stosic (eds.), Les prépositions complexes dans les langues romanes, 176-203. Special issue of Revue Romane 54(1), Amsterdam \& Philadelphia: John Benjamins.

Fagard, Benjamin, \& Walter De Mulder. 2007. La formation des prépositions complexes: grammaticalisation ou lexicalisation? Langue française 156. 9-29.

Fagard, Benjamin. (To appear). Prépositions et locutions prépositives. In Christiane Marchello-Nizia, Bernard Combettes, Sophie Prévost, \& Tobias Scheer (eds.), Grande grammaire historique du français. Berlin \& New York: Mouton de Gruyter.

Fagard, Benjamin. 2006. Evolution sémantique des prépositions dans les langues romanes : illustrations ou contre-exemples de la primauté du spatial ? University Paris 7 \& University Rome 3 Dissertation.

Fagard, Benjamin. 2010. Espace et grammaticalisation - L'évolution sémantique des prépositions dans les langues romanes. Sarrebruck: Editions Universitaires Européennes.

Fagard, Benjamin. 2012. Prépositions et locutions prépositionnelles: la question du renouvellement grammatical. Travaux de linguistique 64(1). 161-189. 
Fagard, Benjamin, José P. Lima, \& Dejan Stosic (eds.). 2019a. Les prépositions complexes dans les langues romanes. Special issue of Revue Romane 54(1). Amsterdam \& Philadelphia: John Benjamins.

Fagard, Benjamin, José P. Lima, \& Dejan Stosic. 2019b. Les prépositions complexes dans les langues romanes. In Benjamin Fagard, José P. Lima, \& Dejan Stosic (eds.), Les prépositions complexes dans les langues romanes. Special issue of Revue Romane 54(1), Amsterdam \& Philadelphia: John Benjamins. 1-7.

Găitănaru, Ștefan. 1965. Descrierea locuțiunilor prepoziționale cu genitivul [Description of complex prepositions with the genitive]. Limba Română [Romanian language], 3-4. 87-92.

Găitănaru, Ștefan. 1999. Criteriile deosebirii locuțiunilor prepoziționale cu genitivul de grupările libere, analizabile [Criteria for distinguishing complex prepositions with the genitive from free, analyzable sequences]. Limba și literatura română [Romanian language and literature] XXVIII ( 2). $12-14$.

Gougenheim, Georges. 1950. Valeur fonctionnelle et valeur intrinsèque de la préposition 'en' en français. Paris : Grammaire et Psychologie.

Gougenheim, Georges. 1959. Y a-t-il des prépositions incolores en francais ? Le francais Moderne 27(1). 125.

Gross, Gaston. 2006. Sur le statut des locutions prépositives. Modèles linguistiques 53. 33-50.

Hagège, Claude. 2010. Adpositions. Function-marking in human languages (Oxford Studies in Typology and Linguistic Theory). Oxford \& New York: Oxford University Press.

Hamp, Carl. 1888. Die zusammengesetzten Präpositionen im Lateinischen. Archiv für lateinische Lexikographie und Grammatik 5. 321-368.

Haspelmath, Martin. 1997. From space to time - Temporal adverbials in the World's Languages. München \& Newcastle: Lincom Europa.

Heine, Bernd. 1989. Adpositions in African languages. Linguistique africaine 2. 77-127.

Heine, Bernd. 2003. Grammaticalization. In Brian D. Joseph \& Richard D. Janda (eds.). Handbook of historical linguistics, 575-601. Oxford: Blackwell.

Hill, Steven 2012. The N-Factor and Russian Prepositions. Their Development in $11^{\text {th }}-20^{\text {th }}$ Century Texts. Berlin: De Gruyter.

Hoffmann, Sebastian. 2004. Are Low-Frequency Complex Prepositions Grammaticalized? On the Limits of Corpus Data - and the Importance of Intuition. In Hans Lindquist \& Christian Mair (eds.), Corpus Approaches to Grammaticalization in English, 171-210. Amsterdam \& Philadelphia: John Benjamins.

Hoffmann, Sebastian. 2005. Grammaticalization and English Complex Prepositions. A corpus-based analysis. London \& New York: Routledge.

Hopper, Paul, \& Elizabeth C. Traugott. [1993] 2003. Grammaticalization. Cambridge: Cambridge University Press.

Huddleston, Rodney. 1984. Introduction to the Grammar of English. Cambridge: Cambridge University Press.

Huddleston, Rodney, \& Geoffrey Pullum. 2002. The Cambridge Grammar of the English Language. Cambridge: Cambridge University Press.

Hüning, Matthias. 2014. Over complexe preposities en convergentie. In Freek Van de Velde, Hans Smessaert, Frank Van Eynde, \& Sara Verbrugge (eds.). Patroon en argument. Een dubbelfeestbundel bij het emeritaat van William Van Belle en Joop van der Horst, 433-445. Leuven: Universitaire Pers Leuven.

Jürine, Anni, \& Külli Habicht. 2013. Kaassõnade tsükliline areng. [The cycle of postpositions] Keel ja Kirjandus [Language and Literature] 12. 736-749.

Jürine, Anni, \& Külli Habicht. 2017. Grammaticalization of complex items: Estonian nii et 'so that', 'so'. Journal of Estonian and Finno-Ugric Linguistics 8(2).

Jürine, Anni. 2016. The development of complex postpositions in Estonian: a case of grammaticalization via lexicalization. Dissertationes Philologiae Estonicae Universitatis Tartuensis vol. 38 . 
Kailuweit, Rolf. 2001. Lexeme, Kasusmarker, Relatoren? Überlegungen zu den spanischen Präpositionen unter dem Aspekt der Grammatikalisierung. In Barbara Schäfer-Prieß, Hildegard Klöden, \& Rolf Kailuweit (eds.), Grammatikalisierung in den iberoromanischen Sprachen, 33-62. Wilhelmsfeld: G. Egert.

Klégr, A leš. 2002. English Complex Prepositions of the Type in Spite of and Analogous Sequences. A Study \& Dictionary. Prague: The Karolinum Press, Charles University.

Kurzon, Dennis, \& Silvia Adler (eds.). 2008. Adpositions: Pragmatic, semantic and syntactic perspectives. Amsterdam \& Philadelphia: John Benjamins.

Leeman, Danielle. 2007. De la préposition à la locution prépositionnelle. La préposition en français. Modèles linguistique 55. 7-15.

Lehmann, Christian, \& Christel Stolz. 1992. Bildung von Adpositionen im Deutschen. Erfurt: Seminar für Sprachwissenschaft der Universität Erfurt(ASSidUE, 6).

Lehmann, Christian. 1985. Latin case relations in typological perspective. In Christian Touratier (ed.). Syntaxe et latin. Actes du IIme Congrès International de Linguistique Latine, Aix-en-Provence, 2831 mars 1983, 81-104. Aix-en-Provence: Université de Provence.

Lehmann, Christian. 1992. Yukatekische lokale Relatoren in typologischer Perspektive. Zeitschrift für Phonetik, Sprachwissenschaft und Kommunikationsforschung 45. 626-641.

Lehmann, Christian. 1995. Synsemantika. In Joachim Jacobs, Arnim von Stechow, Wolfgang Sternefeld, \& Theo Vennemann (eds.). Syntax: Ein internationales Handbuch zeitgenössischer Forschung, 1251-1266. (Handbücher der Sprach- und Kommunikationswissenschaft, 9/2.). Berlin: Walter de Gruyter.

Lehmann, Christian. 2002. New Reflections on Grammaticalization and Lexicalization. In Ilse Wischer, Gabriele Diewald (eds.) New Reflections on Grammaticalization, 1-18. Typological Studies in Language 49. Amsterdam \& Philadelphia: John Benjamins.

Lehmann, Christian. 2015 ( $3^{\text {rd }}$ edition). Thoughts on grammaticalization. Munich: Lincom Europa.

Lesz-Duk, Maria. 2007. Wtórne przyimki przyczynowe we współczesnym języku polskim. [Secondary causal prepositions in modern Polish]. Prace naukowe Akademii im. Jana Dlugosza w Częstochowie VI. 67-73.

Libert, Alan R. 2013. Adpositions and Other Parts of Speech. Frankfurt am Main: Peter Lang.

Lima, José P. 2014. Grammaticalization of complex prepositions in European Portuguese. In José P. Lima, Studies on Grammaticalization and Lexicalization, 163-183. Munich: Lincom Europa.

Lima, José P. 2019a. On grammaticalized complex prepositions in Portuguese: Deployment, shift, redundancy, complementation. In Benjamin Fagard, José P. Lima, \& Dejan Stosic (eds.). Les prépositions complexes dans les langues romanes. Special issue of Revue Romane 54(1), Amsterdam \& Philadelphia: John Benjamins. 126-140.

Lima, José P. 2019b. Preposições complexas em Português [Complex prepositions in Portuguese]. In Ernestina Carrilho, Ana M. Martins, Sandra Pereira, \& João P. Silvestre (orgs.), Estudos linguísticos e filológicos oferecidos a Ivo Castro [Linguistic and philosophical studies offered to Ivo Castro], 1181-1211. Lisboa: Centro de Linguística da Universidade de Lisboa. [https://repositorio.ul.pt/handle/10451/39619]

Lindqvist, Christer. 1994. Zur Entstehung der Präpositionen im Deutschen und Schwedischen. Tübingen: Max Niemeyer Verlag.

Mardale, Alexandru. 2009. Sur la distinction entre prépositions lexicales et prépositions fonctionnelles. In Rodica Zafiu, Blanca Croitor, \& Ana-Maria Mihail (eds.), Studii de gramatică. Omagiu Doamnei Profesoarei Valeria Guţu-Romalo [Grammar studies. Tribute to Professor Valeria GuţuRomalo], 115-125. Bucharest: Editura Universităţii din Bucureşti.

Mardale, Alexandru. 2011. Prepositions as a semilexical category. Bucharest Working Papers in Linguistics XIII(2), 35-50. Bucharest: Editura Universităţii din Bucureşti.

Meibauer, Jörg. 1995. Komplexe Präpositionen - Grammatikalisierung, Metapher, Implikatur und division of pragmatic labour. In Frank Liedtke (ed.), Implikaturen (Linguistische Arbeiten 343), 47-74. Tübingen: Niemeyer.

Melis, Ludo. 2003. La préposition en français. Paris: Ophrys. 
Mrazović, Pavica. 2009. Gramatika srpskog jezika za strance [Serbian grammar for foreigners]. Novi Sad: Izdavačka knjižarnica Zorana Stoja-novića.

Nowak, Tomasz. 2008. Przyimki lokatywno-inkluzyjne we wspótczesnym języku polskim. [Locativeinclusive prepositions in modern Polish]. Katowice: Wydawnictwo Uniwersytetu Śląskiego.

Petit, Daniel. 2015. Les prépositions nominatives de l'albanais. Bulletin de la Société de Linguistique CX(1). 359-443.

Pinkster, Harm. 1990. The development of cases and adpositions in Latin. In Harm Pinkster \& Inge Genee (eds.), Unity in diversity. Papers presented to Simon C. Dik on his 50th birthday, 195-209. Dordrecht: Foris.

Piunno, Valentina, \& Vittorio Ganfi. 2017. Preposizioni complesse in italiano antico e contemporaneo. Grammaticalizzazione, schematismo e produttività. Archivio Glottologico Italiano, CII(2). 184204.

Pottier, Bernard. 1962. Systématique des éléments de relation. Paris: Klincksieck.

Schwenter, Scott, \& Elizabeth C. Traugott. 1995. The semantic and pragmatic development of substitutive complex prepositions in English. In Andreas Jucker (ed.), Historical pragmatics, 243273. Amsterdam \& Philadelphia: John Benjamins.

Seppänen, Aimo, Rhonwen Bowen, \& Joe Trotta. 1994. On the so-called complex prepositions. Studia Anglica Posnaniensia 24. 3-29.

Sigurd, Bengt. 1993. The problems of multi-word prepositions and subjunctions. Working Papers in Linguistics 40. Lund University, Dept. of Linguistics and Phonetics. 197-212.

Spang-Hanssen, Ebbe. 1963. Les prépositions incolores du français moderne. Copenhague: Gads Forlag.

Stathi, Katerina. Forthc. Die Entstehung der komplexen Präposition in Richtung im Deutschen: Zur Emergenz und Verfestigung von Konstruktionen. In Alexander Lasch \& Alexander Ziem (eds.), Konstruktionsgrammatik VI. Historische Konstruktionsgrammatik: Konvergenzen und Divergenzen im Sprach- und Konstruktionswandel. Tübingen: Stauffenburg.

Stefanowitsch, Anatol. Forthc. Complex prepositions of contrast and opposition in English. In Marcin Grygiel \& Barbara Lewandowska-Tomaszczyk (eds.), Contrast and analogy in language: Perspectives from cognitive linguistics. Amsterdam \& Philadelphia: John Benjamins.

Stosic, Dejan. 2012. En passant par : une expression en voie de grammaticalisation? CORELA HS-12, Special issue Langue, espace, cognition, http://journals.openedition.org/corela/2844. https://doi.org/10.4000/corela.2844.

Stosic, Dejan, \& Benjamin Fagard. 2019. Les prépositions complexes en français. Pour une méthode d'identification multicritère. In Benjamin Fagard, José P. Lima, \& Dejan Stosic (eds.), Les prépositions complexes dans les langues romanes. Special issue of Revue Romane 54(1). Amsterdam \& Philadelphia: John Benjamins. 8-38.

Svorou, Soteria. 1994. The Grammar of Space. Amsterdam \& Philaldelphia: John Benjamins.

Šiganova, Galina Aleksandrovna 2001. Sistema leksičeskix $i$ frazeologičeskix predlogov $v$ sovremennom russkom jazyke [The system of lexical and phrasal prepositions in Contemporary Russian]. Unpublished PhD dissertation, University of Tobol'sk.

Vaguer, Céline. 2006. Bibliographie générale : recueils et articles consacrés aux prépositions du français. Modèles linguistiques 54 (XXVII-2). 171-203.

Vandeloise, Claude. 1986. L'espace en français : sémantique des prépositions spatiales. Paris: Seuil.

Veismann, Ann, \& Mati Erelt. 2017. Kaassõnafraas [The Adpositional Phrase]. In Mati Erelt \& Helle Metslang (eds.), Eesti keele süntaks [Estonian Syntax], 446-462. Eesti Keele Varamu [Estonian language library] vol. 3. Tartu: Tartu University Press.

Veland, Reidar. 2011. Le locuzioni preposizionali $a(d)$ opera di, per opera di, per mano di in italiano contemporaneo: funzionamento sintattico e proprietà semantiche. Zeitschrift für romanische Philologie 128(3). 537-552.

Villada Moirón, María Begoña, \& Gosse Bouma. 2003. A corpus-based approach to the acquisition of collocational prepositional phrases. In Proceedings of the Tenth EURALEX International Congress, EURALEX 2002, 153-158. Copenhagen, Denmark, August 13-17, 2002.. 
Waters, Cathleen. 2009. The preposition cycle in English. In Elly van Gelderen (ed.), Cyclical change. Linguistics today 146. 285-301.

Zelinsky-Wibbelt, Cornelia. 1993. The Semantics of Prepositions - From Mental Processing to Natural Language Processing. Berlin \& New York: De Gruyter Mouton. 